\title{
EVALUATION OF POLICIES FOR REGIONAL DEVELOPMENT: UNIFESSPA ACTIONS FOR SOCIAL INCLUSION AND EMPOWERMENT IN PARÁ AMAZÔNIA
}

Rafael Gonçalves Gumiero (https://orcid.org/0000-0002-6193-8698) ${ }^{1^{*}}$

Ana Maria Lopes Tigre (https://orcid.org/0000-0002-0931-6373)

1 Universidade Federal do Sul e Sudeste do Pará, 68507-600, Marabá-PA, Brasil

*gumiero84@gmail.com

Submitted: 07/10/2020. Accepted: 06/12/2020

Published: 12/12/2020

\begin{abstract}
Objective: The purpose of this article is to compare the actions of UNIFESSPA for the territorial development of the municipalities in their campuses. The second objective is to present the budget management trajectory in the years 2015 to 2020 in the institution, as a source to subsidize the actions of its provinces.
\end{abstract}

Methodology: Institutional documents were analyzed, National Policy for Regional Development (NPRD), 2005, the Institutional Development Plan of UNIFESSPA 2014-2020 and the Management Reports 2015, 2016, 2017 and 2018, and the Budget Management Plans of 2019 and 2020.

Results: The resource framework of UNIFESSPA in the years 2015 to 2020 corroborates to measure the growth of the institution, however, there was a continuous fall in resources from the federal government, via the Ministry of Education, which can hinder the strengthening of the university's actions.

Limitation or implication of the research: The main limitation is related to obtaining the new version of the Institutional Development Plan for the next quadrennium, 2020-2024.

Originality: Present the relationship between (NPRD) and the Federal Government's Program to Support Plans for Restructuring and Expansion of Brazilian Federal Universities, delimited by the case of UNIFESSPA in Southern Pará, from 2013 to 2020.

Keywords: extension education, institutional development plan, reuni, higher education institutions, budget.

\section{AVALIAÇÃO DE POLÍTICAS PARA O DESENVOLVIMENTO REGIONAL: AÇÕES DA UNIFESSPA PARA INCLUSÃO SOCIAL E EMPODERAMENTO NO PARÁ AMAZÔNIA}

\section{RESUMO}

Objetivo: O objetivo deste artigo é cotejar as ações da UNIFESSPA para o desenvolvimento territorial dos municípios dos seus campi. O segundo objetivo é apresentar a trajetória da gestão orçamentária nos anos 2015 a 2020 na instituição de ensino superior, como fonte para subsidiar as ações das suas pró reitorias.

Metodologia: Analisaram-se os documentos institucionais Política Nacional de Desenvolvimento Regional, de 2005, o Plano de Desenvolvimento Institucional da UNIFESSPA 2014-2020 e os Relatórios de Gestão 2015, 2016, 2017 e 2018, e os Planos de Gestão Orçamentárias de 2019 e 2020.

Resultados: O quadro de recursos da UNIFESSPA nos anos 2015 a 2020 corrobora para mensurar o crescimento da instituição, porém, houve a queda contínua de recursos do governo federal, via Ministério da Educação, o que pode prejudicar o fortalecimento das ações da universidade.

Limitação ou implicação da pesquisa: A principal limitação está relacionada à obtenção da nova versão do Plano de Desenvolvimento Institucional para o próximo quadriênio, 2020-2024.

Originalidade: Apresentar a relação entre a Política Nacional de Desenvolvimento Regional (PNDR) com o Programa do Governo Federal de Apoio a Planos de Reestruturação e Expansão das Universidades Federais Brasileiras, delimitado pelo caso da UNIFESSPA no Sul do Pará, de 2013 a 2020.

Palavras-chaves: educação extensionista, plano de desenvolvimento institucional, reuni, instituições de ensino superior, orçamento. 


\section{INTRODUCTION}

The Amazonia regional planning was linked to different federal government development policies agendas to reduce regional inequalities, marked out by different approaches. A pioneer creation of the Amazon Economic Enhancement Plan (PVEA), inserted in the 1946 Constitution, where land occupation was the main objective. While in 2007, the formulation of National Policy for Regional Development (PNDR), tutored by Ministry of Regional Development (MDR), prioritized territorial asymmetries and social inclusion. Stoffel et al. (2019), point out that PNDR started to treat the reduction of regional inequalities, historically built during the country's territorial formation and aggravated by market dynamics.

From the scope it can embrace a long period of appraisal of the politicies for the regional development (Macedo et. al., 2017; Macedo and Porto, 2018; Feitosa and Aranha, 2020), this article comprehend as analytical scope the educational politics performed by Support Program for Federal University Restructuring and Expansion Plans (REUNI), of the Ministry of Education (MEC) which made up an important subsidy associate with the proposal guidelines by PNDR as an alternative for the overcoming regional inequalities in the interior of Brazil, most precisely the South of the Pará state.

The formulation of the National Regional Development Fund (FNDR) for the effectuation of the PNDR, would fulfill the fundamental function for the expansion of resources intended for the productive sector in infrastructure and the research activities and development, aiming to strengthen the technological infrastructure, what could ensure the expansion of productivity and better employment conditions for the work-people in the macro-regions North, Northeast and Midwest. In 2008, was sent to Special Committee of the Chamber of Deputies as the PEC $\mathrm{n}^{\circ} 233$, the creation proposal of FNDR, as part of the tax reform of the executive might. The report was approved at Special Commission, however, it didn't go forward for the appraisal at the Plenary of the Chamber of Deputies, which compromised the creation of these financing funds.

The absence of implementation FNDR weakened the implementation of the PNDR guidelines in the territories and as an alternative the federal government proposed an articulation of this politics with the development programs and the social inclusion, to prevent your standstill. Based on this context, and with the intention of reducing the shortage data of PNDR investments, concern pointed out by Stoffel et al. (2019), the purpose of this article is to compare the actions of UNIFESSPA for territorial development in the counties of their campuses, as a possibility for reducing the territorial asymmetries in southern Pará. The specifics objectives are divided in the first place in learn the institutional design of the PNDR treatment linkage for the micro-regions and UNIFESSPA's actions for the territorial development in the counties that constitute your action area, Marabá, Rondon do Pará, Xinguara, Santana do Araguaia and São Felix do Xingu. In second place it's intended to present the budget management of UNIFESSPA trajectory in the period from 2015 to 2020, as a fundamental source to subsidize the actions of their pro rectories.

The methodology applied in this research adopts Amartya Sen's fundamentals to prioritize education as a strategy for the development of individuals, education being an important parameter for growth (Xiang et al., 2020; Walker, 2020). The institutional documents evaluated were: UNIFESSPA Institutional Development Plan 2014-2020 and the Management Reports 2015, 2016, 2017 and 2018, and the Budget Management Plans of 2019 and 2020, formulated by the Secretary for Planning and Institutional Development (SEPLAN) of UNIFESSPA. Also launched a look at the National Regional Development Policy, of 2005, and PNDR in two stages: the apprehended experience and the post 2010 look, formulated by Ministry of National Integration, and the Education Development Plan (2007) of Ministry of Education.

The article is formed in addition to this introduction and the final considerations, by thee topics. The first topic presents the idea of development from the perspective of educational public policy and how this strategy can be implemented from the perspective of multiscale planning. The second topic presents the relationship established between the PNDR on your second step, 2010- 
2015, and the REUNI, as a strategy for the development of micro-region by expansion of the higher education network to the interior of Brazil.

\section{THEORETICAL REFERENCE}

\subsection{The educational policy planning approach as a strategy for regional development}

The first movement realized in this article is to present the concept of development, which allows to mobilize a great theories arena, ideas, concepts (Gao et al., 2019; Gentil et al., 2019; Grisotti et al;, 2020; Abdal, 2020; Santos and Pereira, 2020), allowing us to understand the formation of lineages of thought about the repositioning of education as one of the main parameters for the formulation of a development policy for underdeveloped countries. But, within this great theoretical capital that the referred concept can cover, we'll limit the relationship established between the concept of education as a powerful strategy for the development and how it can impact in the reduction of territorial asymmetries (Pinheiro et al., 2016; Vicente et al., 2020).

The author Amartya Sen (2000), in your work Development as Freedom, of 1999, approached development under an interpretive key based on the relationship of this concept with social opportunities, for the freedom of individuals to have access to economic, social and political activities, and how individual privations of access to these dimensions can cause poverty (SEN, 2000). In Sen's view, poverty "should be seen as a privation of basic skills rather than merely as low income, which is the traditional criterion for identifying poverty", with public policy action to overcome poverty being paramount.

In stating that poverty starts from privation of basic skill, the cut of public policies must be prioritized by the State (Deneulin \& Clausen, 2019; Mok \& Jeong, 2019; Jung, 2020), as a promoter of social rights to grant freedoms to the population. Sen (2000), presents the definition of "poverty by income" and "poverty by capacity" and warns about the limitations of the individual's privation of opportunities by income.

The freedom for Sen is the primary means for development, the instrumental freedoms is "the way in which different types of rights, opportunities and titles contribute to the expansion of human freedom" (Sen, 2000, p. 53). Among them, we can refer to social opportunities, which can be constituted by public policies directed to the areas of education and health for the participation of individuals in economic activities. That way, freedom is the way to overcome poverty and the role of the State is to act in the eradication of poverty through the formulation of policies that guarantee basic social opportunities for everybody.

Poverty can be analyzed with different analytical and empirical approaches. Poverty in the region emerges as a problem that is difficult to resolve in underdeveloped countries. Sen's thesis (2000) was positioned to present subsidies to investigate poverty, which under the territorial perspective emphasizes the need for State action in the formulation of public policies, engaged in the specialization of education, understood as a key to the empowerment and capacity of the population.

In the work "Território \& Desenvolvimento: as múltiplas escalas entre o local e o global", in 2007, the author Carlos Brandão strongly criticizes the localist perspectives, unrelated to the multiscale strategy of national planning. The actions implemented in the territory must be related to macro-regional agencies for the formulation of a policy for regional development, made possible by the federative dialogue between the federal, state and municipal governments, with the participation of civil society in decision-making at the local scale.

Brandão's definition of territory is combined with multiple scales, "it is necessary to discuss the specialty of the problems and implement policies taking into account the specific scale of these problems, but in a context where a national development project is present" (Brandão, 2007, p. 36). In a view of the multiple scales between the local and the global, and concerns about reducing 
regional and intraregional inequalities with the integration of multiple spatial scales (Feitosa and Aranha, 2020; Dota and Ferreira, 2020), the urgency to organize a national policy for regional development is reinforced, adapting to different scales and territorial specificities.

For Brandão (2007), the local peripheral regions scale is more vulnerable to the structural formation of these forms of domination, which are related to land, patriarchal practices of economic accumulation and restriction, elitist influence in all local decision-making. The above-mentioned author says that is necessary to establish direct and effective relationships between scales through national policies for regional development, imbued with the task of "insert a growing share of this social and urban material in full citizenship, building social justice, ensuring the access to public good and services" (Brandão, 2007, p. 212).

In the years 2003 to 2015 , federal government's investment prioritized priority sectors in the economy and the redistribution of income with social inclusion of the population. For Brandão (2019), these financial resources were concentrated by the territorial inertia of the coast and metropolises of Brazil. With the exception of enclave points in interior regions of Brazil, resulting from the expansion of commodity extraction and production. In the mainstay of this process, the aforementioned author identified in the Carajás sub-region, in Pará, investments by the federal government with priority in the preamble major infrastructure works and in economic logistics for the extraction and production of agricultural and mineral commodities. The absence of democratic deliberative goals in the decision-making processes among the population with public managers, prevented the adjustment between local demands with the projects concerned, and financial resources have been implanted in projects limited to the productive and extractive centers of commodities, that enhanced the territorial asymmetries in the Carajás sub-region.

The State took a leading role in infrastructure programs, especially in energy works in Pará. The justification for choosing the locations for the PAC works came from natural competitive advantages, linked to the mineral and especially geographic location, so that there was no space for negotiation with the federative entities about its realization. Municipalities were given specific roles, in a subordinate form in decision-making processes for the implementation of PAC works in the territories under their local management (Lotta and Favareto, 2018).

Abdal (2020) says that there is a requirement to revise the research agenda on regional development to focus on the process of productive fragmentation that has been intensified in recent years in the North and Midwest regions. In the years 2000 and 2010, regional asymmetries started to have a strong intra-regional profile, driven by the production and extraction processes of agricultural and mineral commodities. Because of this, it is necessary to dwell on measuring the direct and indirect effects generated by public policies implemented by the federal, state and municipal instances in the territories of these regions.

In the next topic, the relationship between PNDR and REUNI is presented, as a strategy for multiscale development with priority on the diversity of the microregions, due to the focus on expanding the network of higher education to the interior of Brazil and the formation of local economic dynamics.

\subsection{The joint action formed by the territorial taxonomy of the PNDR and the interiorization of higher education by REUNI}

The first version of the National Policy for Regional Development (PNDR) was presented in 2003. The PNDR was institutionalized through Decree № 6.047 of February 22, 2007, which signaled flashes of hope for the resumption of the regional issue. The singularity of this policy in relation to other initiatives for regional planning was established by the central objectives marked by the Policy Eligibility Map, by the National Fund for Regional Development (FNDR) and a new model of public management, articulated by promoting dialogue between civil society and 
government institutions. The taxonomy formulated according to the variables average household income and GDP growth per capita of the municipalities was a method for the intervention of this policy in the territory. The result was the identification of four groups formed by high-income, dynamic, stagnant and low-income micro-regions (BRASIL-MI, 2005).

The variables used in the PNDR taxonomy methodology presented in the first variable the relative wealth of the population and in the second, the relative potential for economic growth. So that this crossing results in four groups of micro-regions (MRGs), whose priority for the reduction of socioeconomic vulnerabilities are those of low income, stagnant income and dynamic income. The first group of micro-regions has a consolidated standard of competitiveness, the second group are territories in the process of economic incorporation into the national dynamics, the third group has a prolonged pattern of stagnation and the fourth group has economic weakness (MI-BRASIL, 2005).

The PNDR got a second version and was reformulated in 2010, its guidance was improved to implement three axes of objectives and its guidelines for the development of micro-regions. The first was the creation of the eligibility map that indicated the priority in resource application in micro-regions, in order to provide actions for citizenship and strengthening the endogenous capacity of economic dynamics. The second axis was the readjustment proposal of FNDR to finance the PNDR. But, the freezing of the procedure for the institutionalization of the FNDR proposal required that other sources of financing, constitutional funding funds, be mobilized for the functioning of the PNDR. The third axis was the narrowing between the proposed project agenda organization for the participation of the population of the micro-regions in the plenary sessions (MI-BRASIL, 2010).

Due to the absence of FNDR approval, the Constitutional Financing Funds, Constitutional Fund for Financing the North (FNO), Constitutional Fund for Financing the Northeast (FNE), Constitutional Fund for Financing the Midwest (FCO) started to be implemented according to the guidelines of the PNDR, priority intended for micro and small rural and business entrepreneurs in micro-regions identified as low and stagnant income (Macedo et al., 2017). According to Macedo, Pires and Sampaio (2017), the Constitutional Financing Funds from 2003 to 2015 were boosted, in terms of volume of resources and number of operations due to the new credit modalities incorporating the operations of the National Program for Strengthening Family Agriculture (PRONAF) and financing of infrastructure and commercial enterprises, combined with proactive actions by the banks managing these finances. The actions of creditor banks to reduce defaults and recover debtors' debts are added. Another highlight was the expansion of the opening of new branches of Banco da Amazônia and the Northeast, complemented by the strategy of reducing interest rates.

Credits for small and micro rural producers contributed to the reduction of rural territorial asymmetries between large agricultural enterprises, in order to allow the economic inclusion of these rural agents, which is one of the strategies of the PNDR, the productive promotion and adding value to small rural productive enterprises. Allied to this strategy, the performance of its plans runs through: social inclusion and income generation.

In the PNDR, the social inclusion was positioned as an action for implementation in the territories through the merger with the Education Development Plan (PDE), as a mechanism for reducing social and regional asymmetries for social equity. The PDE was launched by the federal government in 2007, under the management of the Ministry of Education, Fernando Haddad, who presented the idea of education models associated with the ordering of the territory with economic and social development, to meet the different demands of the population (BRASIL-MEC, 2007).

The PDE prioritized social responsibility and mobilization (accountability), understood as the creation of spaces for dialogue between representatives of the federal government and the demands of civil society. The PDE has six vectors that direct its actions: education systemic view; territoriality; development; collaboration regime; accountability and social mobilization, which are a consequence of constitutional principles and objectives, in order to express the necessary link 
between education, territory and development, and the combination of quality, equity and potential (BRASIL-MEC, 2007).

The PDE strategy was guided by the binomial education and socioeconomic development, articulated according to the demands of the territory, organized by the logic of the local, regional or national educational arrangement. The PDE represented more than 40 strategic programs, implemented by the government through the division into axes: basic education; literacy and continuing education; professional and technological education; and higher education. The interaction between education and territorial development search to foster citizenship, being more than the rescue of the historical debt of the population excluded from access to social rights in the territory, but as a result of a policy of social inclusion (BRASIL-MEC, 2007).

According to Marques and Cepêda (2012) the expansion process of public universities under the tutelage of REUNI wasn't unique, it was initially presented by the Education Development Plan (PDE) to reduce asymmetries and expand inclusion. The aforementioned authors pointed out five main characteristics: i) quantitative expansion: increase in institutions, vacancies, campuses; ii) geographic expansion: expansion seeking the interiorization of institutions aiming at regional integration on three fronts - metropolitan peripheries, state borders and enclaves and international borders; iii) expansion of functions: aiming at local, sustainable development of a multicultural character, generation of autonomy and identity awareness to underrepresented groups demanding rights for recognition; iv) expansion of access: different mechanisms in the form of access assessment such as the use of ENEM / SISU and the Affirmative Action law; v) expansion of stay: aiming to establish mechanisms for the permanence of students in situations of social vulnerability.

The REUNI emerged with the aim of expanding the offer of public higher education. As soon, the program was the main political action in recent years to expand vacancies and courses at federal universities and federal institutes, through the immobilized physical and personnel restructuring (Paula e Almeida, 2020). REUNI presented as an alternative to the regional disparities in Brazil, ways for students to enter public higher education through the creation of new federal university units and federal institutes in border and interior regions as a mechanism to enhance local and national integration. The creation of new universities or units sought to meet the socio-cultural characteristics of the territory and offer vacancies in undergraduate courses and courses related to the regional vocation of work (Marques and Cepêda, 2012).

In a first movement, REUNI aimed to implement universities in the border region, as in the case of UFFS and UNILA, together with UFOPA and UNILAB. The second movement of REUNI was the expansion for consolidation 2012-2014 with the creation of four more federal universities UNIFESSPA (University of the South and Southeast of Pará, with headquarters in Marabá), UFRC (Federal University of the Region of Cariri, with headquarters in Juazeiro do Norte - CE), UFBA (Federal University of Western Bahia, headquartered in Barreiras) and UFESBA (Federal University of Southern Bahia, headquartered in Itabuna) (Marques and Cepêda, 2012).

In the next topic, UNIFESSPA's strategy for territorial development is addressed, guided by its institutional development plan and the actions carried out by its pro-rectories aimed at the permanence of students of high socioeconomic vulnerability in the university and the external community. 


\section{PROCEDURES AND METHODS}

Research carried out internationally by supranational institutions, such as the Economic Commission for Latin America and the Caribbean (ECLAC) and the Economic Organization for Cooperation and Development (OECD) repositioned the agenda around the impacts generated by the expansion and diffusion of higher education to the territories. The Study of Education and Knowledge: Eure of the Productive Transformation with Equity, by ECLAC, 1992, repositioned education as a strategy between productive and social articulation that expands the formulation of the know-how of Latin American countries to improve their competitiveness in the circuits of the international economy. The axes of productive transformation with equity in underdeveloped countries is the opening of the "black box" of technical progress, determined by public policies promoted by the State in the areas of education and knowledge (CEPAL, 1992).

In the 2000s, the studies formulated by the OECD, public policies related to higher education institutions were positioned as a strategy for training regional competitiveness combined with regional innovation systems. In addition to the dimension of productivity and innovations, higher education institutions (HEIs) can collaborate to play a role with actors in the territory, including agents, such as private companies and small enterprises. HEIs can collaborate for development by advancing in inland or border regions, offering education to the population and expanding the supply and demand of the labor market, reinforcing the bonds between employers and the creation of companies. This OECD study was applied in dozens of regions in several countries (OECD, 2007).

The PNDR advanced in Pará through the strategies defined by the Regional Sustainable Development Plan (PDRS), based on the Participatory Territorial Planning (PTP) methodology to reduce the economic and social vulnerabilities of the state of Pará. The implementation of REUNI, through the creation of a federal university in the south and southeast of Pará, UNIFESSPA, configured reinforcement in the guidelines of the PNDR with an emphasis on reducing social vulnerability.

University performance evaluation research can help decision makers to understand the development status of higher education more clearly and to reduce the regional gap in the field of higher education more effectively (Zhang et al., 2020). The methodology was based on presenting the conceptions of the micro-regional development of institutional documents National Policy for Regional Development, of 2005, and PNDR in two stages: The experience learned and the post2010 perspective, 2010, formulated by the Ministry of National Integration, the Plan of Education Development, 2007, from the Education Ministry, on the aforementioned topic. And in the next topics, priority was given to the results obtained from the balance sheet of the Institutional Development Plan of UNIFESSPA 2014-2020 and the Management Reports 2015, 2016, 2017 and 2018, and the Budget Management Plans of 2019 and 2020, formulated by the Secretary of Planning and Institutional Development (SEPLAN) of UNIFESSPA.

The objectives of the UNIFESSPA PDI were presented as a guiding axis of its activities in teaching, research and extension through the democratization of access to higher education for the population, with regional development as a priority. The second objective is the expansion of undergraduate and graduate education. The third objective is the development of university extension with research to focus on local and regional development. The fourth objective is to connect the teaching, research and extension tripod with the location. The fifth objective is the formation of innovation by the mentioned tripod and the administration. The sixth objective is to improve programs dedicated to students, to reduce the number of dropouts. The seventh objective is planning related to the evaluation of the results of the actions carried out by the programs and the budget. The eighth objective is to strengthen internal control. The ninth objective is the qualification of the servers. The tenth objective is to expand the physical and technological infrastructure to improve functioning. The eleventh is to organize internal and external communication of the university's activities (UNIFESSPA-SEPLAN, 2020). 
UNIFESSPA is composed of units that support academic activities in teaching, research and extension and can be divided into: Pro-rectory of Undergraduate Education (Proeg); Dean of Graduate Studies, Research and Technological Innovation (Propit); Dean of Extension and Student Affairs (Proex); Secretariat for Planning and Institutional Development (Seplan); Infrastructure Secretariat (Sinfra); Dean of Administration (Proad) and Dean of Management and Personnel Development (Progep); and supplementary organs.

The supplementary organs are: Central Archive; Communication Advisory (Ascom); National and International Relations Advisory (Arni); Internal Audit (Audin); Selection Process Center (Ceps), Academic Registration and Control Center (CRCA), Information and Communication Technology Center (Ctic); Higher Administration Coordination (CAS); Ethics Committee; Own Evaluation Committee (CPA); Permanent Commission for Inquiry and Disciplinary Administrative Procedure (CPPAD); Permanent Teaching Personnel Commission (CPPD); Accessibility and Academic Inclusion Center (Naia); Ombudsman; Library System (Sibi).

\section{RESULTS}

Pará regionalization was created by the state government and strategically positioned for joint government action at the state level through Participatory Territorial Planning (PTP) and the Pluriannual Plan (PPA) 2008-2011, with the federal scale via methodology of the territorial taxonomy of the PNDR, organized by the Secretary for Regional Development (SDR), of the Ministry of National Integration. There was a conciliation of actions between the branches of the Executive Branch, under the axes of decentralization of public administration and the multi-scale approach with territorial treatment, in sub-regions in Pará. The federal government, through the PNDR instituted together with the state government of Pará, the Sustainable Regional Development Plans (PDRS). The state of Pará was divided into 12 integration regions, Araguaia, Baixo Amazonas, Carajás, Guamá, Tucuruí Lake, Marajó, Metropolitana, Rio Caeté, Rio Capim, Tapajós, Tocantins and Xingu (LIMA, 2010).

The UNIFESSPA emerged as a breakup of the Marabá campus of the Federal University of Pará (UFPA), established in 1986, when the UFPA Interior Program was implemented. UNIFESSPA was created in 2013, by federal law number 12.824 . It was the second federal university to be installed in the interior of the Amazon, under a concentration of federal universities in the capitals of the North, Northeast and Midwest macro-regions. UNIFESSPA's strategy runs through the planning of the Institutional Development Plan (PDI), 2014-2020, as a tool that allows administratively organizing the goals and objectives to overcome the diagnosis of the problems identified in society (UNIFESSPA-SEPLAN, 2020).

The implementation process of UNIFESSPA covers the integration regions Carajás and Xingu, with three units of the Marabá Campus and four new campuses: Rondon do Pará, Santana do Araguaia, São Félix do Xingu and Xinguara.

The strategic territory of UNIFESSPA, figure 1, can be understood between the perimeter of the municipalities Marabá (headquarters of the university), and the campuses outside Rondon do Pará, Xinguara, São Felix do Xingu, Santana do Araguaia, and in the Teaching, Research, Extension Pole, Technology and Innovation (Pepeti), with the support of Canaã dos Carajás city hall, in an agreement signed between the government of the aforementioned municipality and UNIFESSPA to offer undergraduate and specialization courses. 


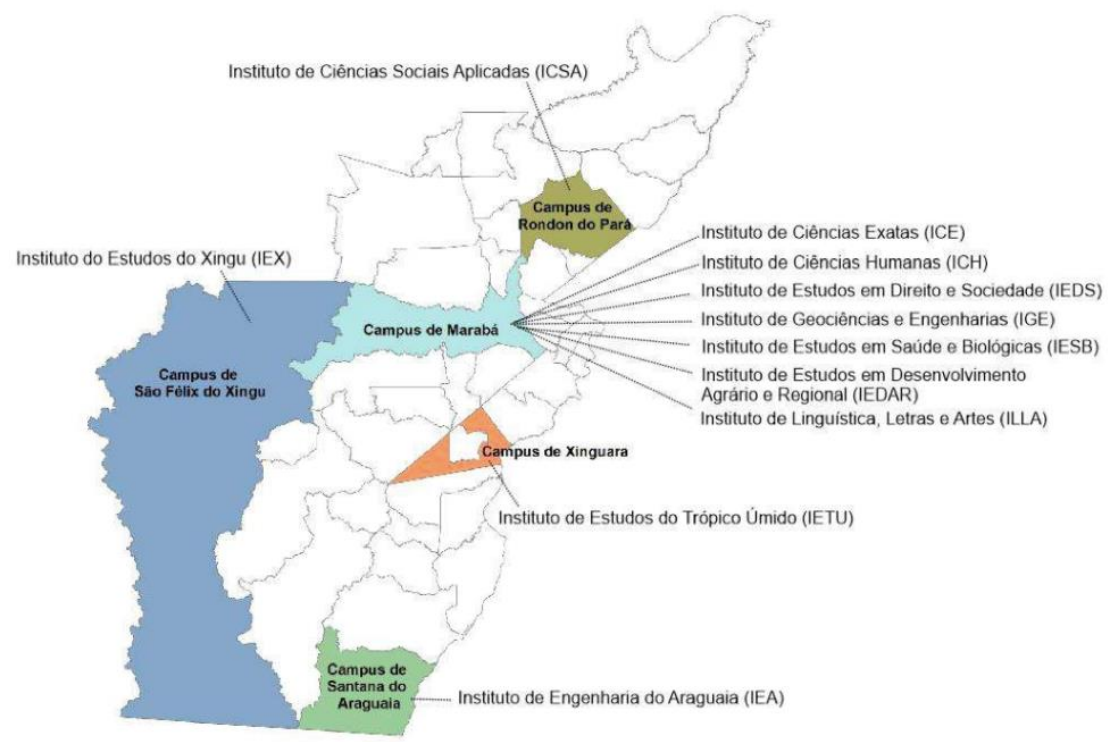

Figure 1 - Map of UNIFESSPA University Campuses Source: SEPLAN (2017b).

The implementation of UNIFESSPA expanded from 16 to 34 undergraduate courses in 2014. And in 2019, it expanded to 43 courses. UNIFESSPA's operating strategy was multicampi, with undergraduate courses in Rondon do Pará, Xinguará, São Felix do Xingu and Santana do Araguaia municipalities.

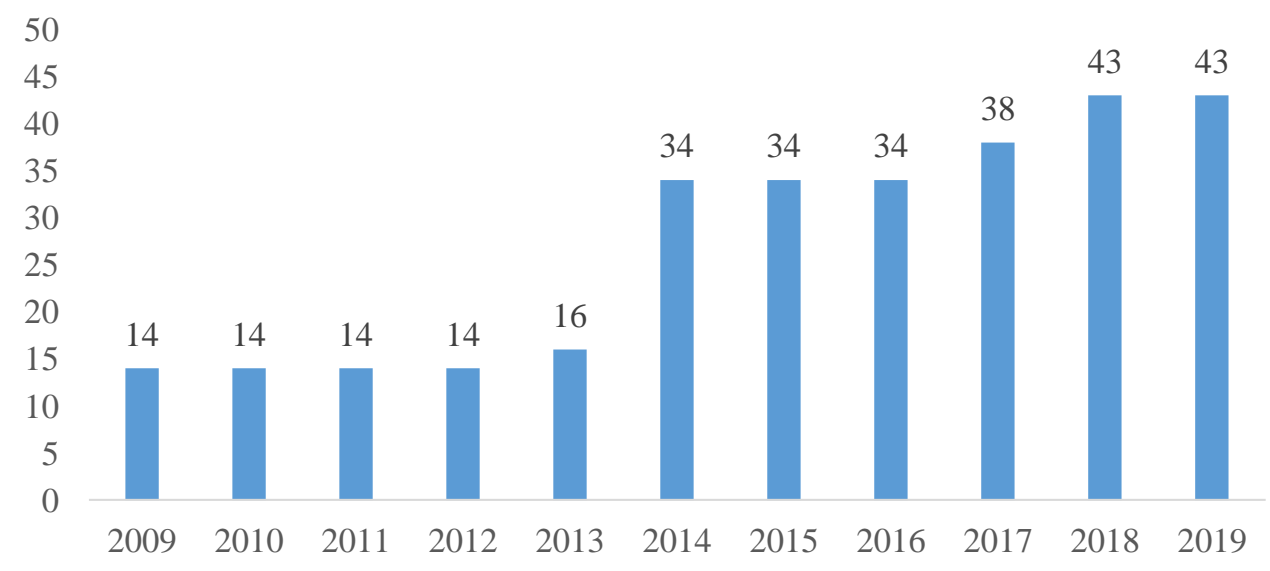

Graphic 1 - Number of undergraduate courses created at UNIFESSPA

Source: SEPLAN (2020b).

In the graph below, in the years 2013 to 2019, the expansion of the opening of new undergraduate courses impacted the increase of the number of undergraduate vacancies offered and the number of students enrolled in UNIFESSPA undergraduate courses. The expansion of the offer of places in UNIFESSPA undergraduate courses was a fundamental factor in seeking to supply the demand for higher education in the interior of Pará. 


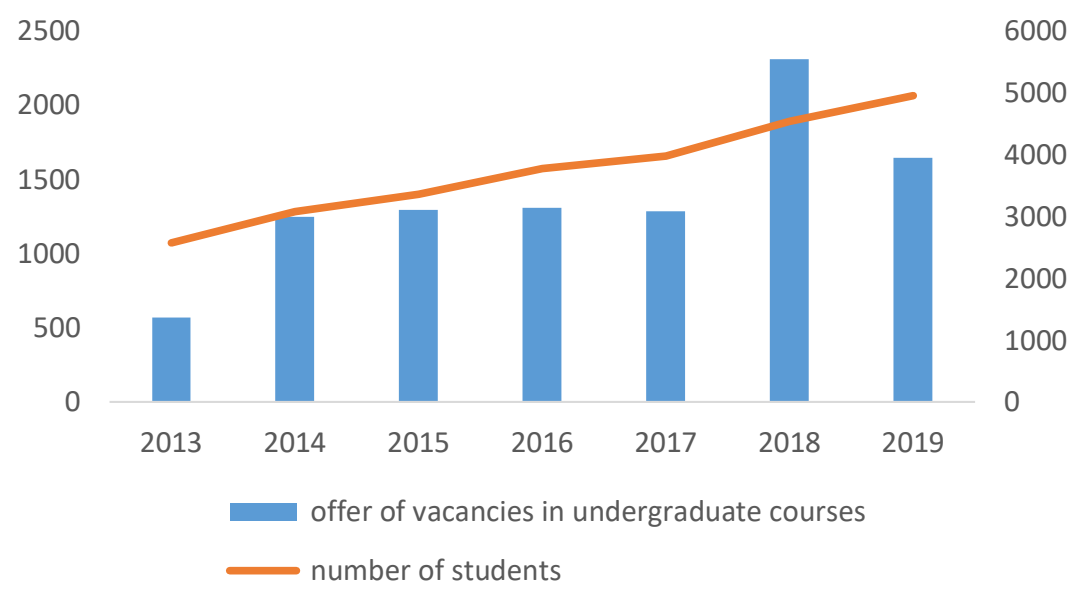

Graphic 2 - Offers of vacancies and students enrolled in UNIFESSPA undergraduate courses Source: SEPLAN (2020b).

The highest percentage of students has the North region as their place of birth, corresponding to $81.2 \%$ and the lowest percentage comes from the Midwest region. Figure 2 complements the picture of the origin of the students' municipalities, in which the highest percentage of students come from municipalities that are located on UNIFESSPA campuses, which demonstrates the adherence of local demand to places offered in undergraduate courses. And, to a lesser extent, students from other municipalities, located in other sub-regions of Pará.

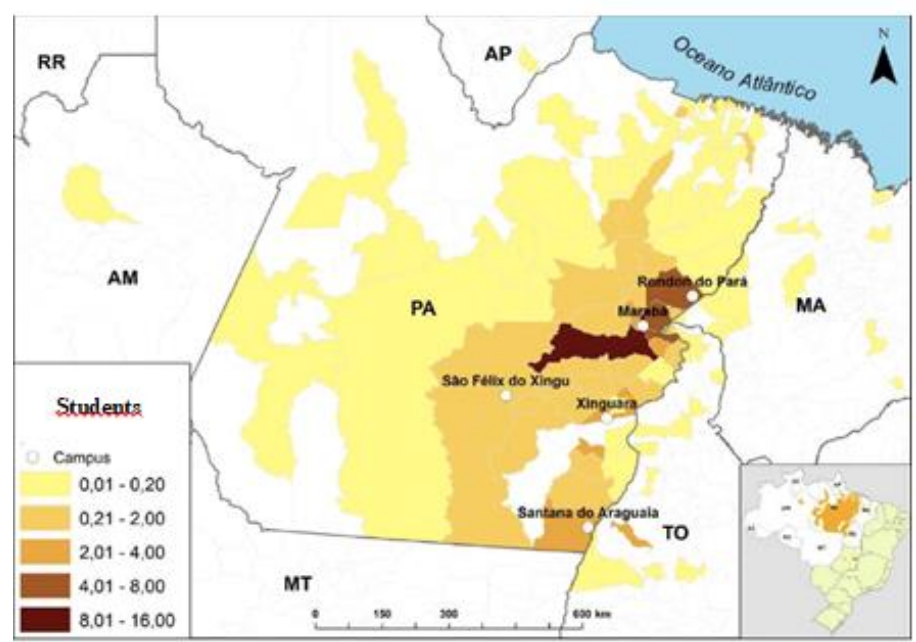

Figure 2 - Municipality of origin of UNIFESSPA students 2014-2018 (in thousand) Source: SEPLAN (2020b).

\subsection{UNIFESSPA's actions for social inclusion and empowerment in Southern Pará}

We highlight the actions of three UNIFESSPA provinces, Proeg, Propit and Proex, whose importance is the programs that can collaborate for the permanence of the student at the university, seeking to reach mainly low-income students who are studying undergraduate and direct extension actions for communities.

The Dean of Education can be characterized by its diagnostic functions and actions to improve undergraduate education in UNIFESSPA courses, highlighted in Table 1. 
Table 1 - PROEG programs

\begin{tabular}{|l|l|}
\hline Program & Objective \\
\hline $\begin{array}{l}\text { Accessibility and } \\
\text { Center (Naia) }\end{array}$ & $\begin{array}{l}\text { Promotion of university accessibility and inclusion programs, divided communication } \\
\text { and information, physical, architectural, programmatic, attitudinal and pedagogical } \\
\text { accessibility. }\end{array}$ \\
\hline $\begin{array}{l}\text { Specific Academic } \\
\text { Support Program (Paae) }\end{array}$ & $\begin{array}{l}\text { Support for students with learning disorder and Attention Deficit Hyperactivity } \\
\text { Disorder (ADHD). }\end{array}$ \\
\hline $\begin{array}{l}\text { Support Program for } \\
\text { Intervention Projects } \\
\text { (Papim) }\end{array}$ & $\begin{array}{l}\text { Pedagogical strategic formulas for teaching-learning in Basic and Professional } \\
\text { Education, with an interface to teaching with research and extension, between Higher } \\
\text { Education and Basic Education }\end{array}$ \\
\hline $\begin{array}{l}\text { General Monitoring } \\
\text { Program }\end{array}$ & $\begin{array}{l}\text { Organized to serve undergraduate students in the curriculum components and to } \\
\text { improve the quality of the teaching-learning process. }\end{array}$ \\
\hline $\begin{array}{l}\text { Monitoring Program for } \\
\text { Disciplines with }\end{array}$ & $\begin{array}{l}\text { It meets the same strategy criteria as the general monitoring program, however, it } \\
\text { extends to undergraduate courses that have greater specificity with laboratory } \\
\text { practices. }\end{array}$ \\
\hline $\begin{array}{l}\text { Quilombola Student } \\
\text { Support Program } \\
\text { (Paequi) }\end{array}$ & $\begin{array}{l}\text { Teaching program aimed at quilombola students regularly registered at the University, } \\
\text { with the aim of supporting immersion in teaching, research and extension activities, } \\
\text { contributing to the objective of increasing the permanence of these students at the } \\
\text { university. }\end{array}$ \\
\hline $\begin{array}{l}\text { Indigenous Support } \\
\text { Program (Paind) }\end{array}$ & $\begin{array}{l}\text { The program is aimed at indigenous students regularly registered at the University, } \\
\text { with the action of perfecting and tutoring actions for teaching, research and extension, } \\
\text { with the objective of preventing the evasion of this public from the university. }\end{array}$ \\
\hline $\begin{array}{l}\text { Incoming Student } \\
\text { Support Program (Padi) }\end{array}$ & $\begin{array}{l}\text { Program aimed at students registered in the 1st and 2nd block of the course, with } \\
\text { access to the support of pedagogical monitoring of the academic content taught in the } \\
\text { first year of the undergraduate course, seeking to facilitate the learning process. }\end{array}$ \\
\hline
\end{tabular}

Source: UNIFESSPA-SEPLAN (2020).

Additionally, the implementation of the Social Inclusion Committee can be incorporated as a strategic action of UNIFESSA, formed from the popular demands of the territory, representatives of civil society, indigenous peoples, quilombolas and people with disabilities, whose objective is to cover their identity demands and actions of university professors and professionals in the inclusion of students, since their entry into the undergraduate and graduate courses. The Basic Education Teacher Training Committee (Comfor), is another action formed by the organization of the collegiate with representatives of professors of UNIFESSPA undergraduate courses, and representatives of the pro-rectories and teachers of the territorial basic education networks. Comfor's objective is to improve the training of basic education teachers.

The pro-rectory of extension (PROEX) is an important function in UNIFESSPA's territorial development strategy, as it mobilizes as objectives the relationship between university community through social, environmental and regional diversity, in order to prioritize social and environmental inequalities. Proex programs and projects, table 2, seek to establish effects on society through the empowerment of individuals, developed by multidisciplinarity and community participation.

Table 2 - Proex Programs

\begin{tabular}{|l|l|l|l|l|l|l|l|}
\hline \multirow{2}{*}{ Action } & \multirow{2}{*}{ Indicator } & \multicolumn{2}{l|}{ Number of customer service } & \multicolumn{2}{l|}{ Projection } \\
\cline { 3 - 8 } & & $\mathbf{2 0 1 4}$ & $\mathbf{2 0 1 5}$ & $\mathbf{2 0 1 6}$ & $\mathbf{2 0 1 7}$ & $\mathbf{2 0 1 8}$ & $\mathbf{2 0 1 9}$ \\
\hline $\begin{array}{l}\text { Implementation of the Institutional Extension } \\
\text { Scholarship Program - Pibex }\end{array}$ & Scholarship & 49 & 52 & 68 & 68 & 70 & 70 \\
\hline Implementation of the Art-Culture-Education Program & Scholarship & 9 & 14 & 12 & 4 & 4 & 4 \\
\hline $\begin{array}{l}\text { Implementation of the Support and Promotion } \\
\text { Program for Cultural and Academic Events }\end{array}$ & Events & 19 & 8 & 5 & - & 20 & 26 \\
\hline $\begin{array}{l}\text { Implementation of the Support Program for the } \\
\text { Democratization of Access to Higher Education }\end{array}$ & Scholarship & 12 & 12 & 15 & 10 & 18 & 10 \\
\hline
\end{tabular}

Source: Proex/Unifesspa.In: UNIFESSPA-SEPLAN (2020). 
The Pro-Rectory of Graduate Studies, Research and Technological Innovation (PROPIT) aims to research, table 3. In undergraduate courses for scientific initiation and in graduate courses for formulating diagnoses and alternatives to overcome regional inequalities.

Table 3 - PROPIT's program 2015 - 2019

\begin{tabular}{|c|c|}
\hline Pro & Objective \\
\hline $\begin{array}{l}\text { Institutional Scholarship Program for } \\
\text { Scientific Initiation and Technological } \\
\text { Development and Innovation }\end{array}$ & $\begin{array}{l}\text { Make feasible the granting scholarship of Scientific and Technological } \\
\text { Initiation to undergraduates under the guidance of researchers from } \\
\text { Unifesspa. }\end{array}$ \\
\hline $\begin{array}{l}\text { Institutional Scholarship Program for } \\
\text { Scientific Initiation High School }\end{array}$ & $\begin{array}{l}\text { Awaken scientific vocation and encourage potential talents among } \\
\text { elementary, high school and professional students from public schools } \\
\text { (appointed to CNPq by the proposing entity), and enable the participation } \\
\text { of high school students in scientific or technological research activities, } \\
\text { guided by a researcher from Unifesspa. }\end{array}$ \\
\hline $\begin{array}{l}\text { Unifesspa Research } \quad \text { Groups } \\
\text { Strengthening Program }\end{array}$ & $\begin{array}{l}\text { Make feasible the granting of financial support for tickets and daily } \\
\text { allowances to researchers invited by professors of the institution to carry } \\
\text { out actions aimed at strengthening the research group. }\end{array}$ \\
\hline rogram & $\begin{array}{l}\text { Make feasible the granting of computer equipment to Unifesspa servers } \\
\text { who obtained the title of doctor in the year prior to the launch of the public } \\
\text { notice. }\end{array}$ \\
\hline Support Program & $\begin{array}{l}\text { Promote the publication of scientific articles authored by civil servants } \\
\text { (teachers and administrative technicians) and students of Unifesspa in } \\
\text { foreign magazines renowned for their respective areas of knowledge. }\end{array}$ \\
\hline $\begin{array}{l}\text { Qualified Publication Incentive } \\
\text { Program for Undergraduate Students. } \\
\text { (Propit / Proex / Proeg partnership) }\end{array}$ & $\begin{array}{l}\text { Reward, with financial value, student of Unifesspa author or co-author of } \\
\text { an article published in qualified journals, as an incentive to scientific } \\
\text { production. }\end{array}$ \\
\hline $\begin{array}{l}\text { Capes doctoral grants awarded by } \\
\text { quota to Unifesspa under the Prod } \\
\text { Doutoral Program }\end{array}$ & $\begin{array}{l}\text { te support for professors who are completely removed from their } \\
\text { activities at Unifesspa to pursue their doctorate degree. }\end{array}$ \\
\hline $\begin{array}{l}\text { Selection and monitoring of fellows } \\
\text { according to Capes guidelines }\end{array}$ & $\begin{array}{l}\text { s, through the } \\
\text { pa. }\end{array}$ \\
\hline $\begin{array}{l}\text { Support for strengthening graduate } \\
\text { programs }\end{array}$ & better conditions \\
\hline $\begin{array}{l}\text { Institutional grant program that } \\
\text { finances post-doctoral internships in } \\
\text { stricto sensu graduate programs } \\
\text { recommended by Capes }\end{array}$ & $\begin{array}{l}\text { Promote the insertion of Brazilian and foreign researchers in post-doctoral } \\
\text { internship, stimulating their integration with research projects developed } \\
\text { by postgraduate programs, reinforcing research groups. }\end{array}$ \\
\hline Interinstitutional Doctorate & $\begin{array}{l}\text { Enable training, at the stricto sensu graduate level, foster academic } \\
\text { production and strengthen lines of research that respond to demands } \\
\text { related to local and regional development. }\end{array}$ \\
\hline $\begin{array}{l}\text { Unifesspa Technological Innovation } \\
\text { Center https://nit.unifesspa.edu.br }\end{array}$ & $\begin{array}{l}\text { Provide support to Unifesspa researchers in the process of patenting } \\
\text { inventions, products and processes generated in research activities and that } \\
\text { can be transformed into benefits for society. } \\
\text { The NIT is the main institution for implementing institutional policy for } \\
\text { the protection and transfer of technology from the university's intellectual } \\
\text { property. }\end{array}$ \\
\hline Junior Companies & $\begin{array}{l}\text { Promote support and strategic guidance for the institutionalization of } \\
\text { junior companies in order to encourage entrepreneurship and business } \\
\text { innovation. }\end{array}$ \\
\hline $\begin{array}{l}\text { Laboratory of Scientific and Applied } \\
\text { Computing }\end{array}$ & $\begin{array}{l}\text { Conduct scientific analysis with the application of mathematical and } \\
\text { computational techniques and models to solve scientific and technological } \\
\text { problems of the several research groups of the Institution, in addition to } \\
\text { providing a distributed and high performance computing environment. }\end{array}$ \\
\hline
\end{tabular}

Source: Propit-UNIFESSPA. IN: UNIFESSPA-SEPLAN (2020).

The distribution of UNIFESSPA's spending by expense groups, divided into costing, capital and personnel decreased over the period 2015 to 2020. The values corresponding to the years 2015 to 2018 are disclosed in the Management Reports, and the values referring to the years 2019 and 2020 are part of the Budgetary Management Plan, that is, there may be changes when the 
management reports corresponding to the aforementioned years. In Graph 1, it is possible to verify that the largest drop in the amount spent corresponds to the capital group, which decreased from R\$ 12.228.475,00 million in 2017 to $\mathrm{R} \$ 3.000 .000,00$ million in the following year. In the following years, 2019 and 2020, the budget forecast made by SEPLAN represents an increase in value, however, if we consider the relative value of the expansion of expenses in the staff group, its technical staff and teachers, it is possible to say that there is a drop in relative value of capital expenditures and university funding.

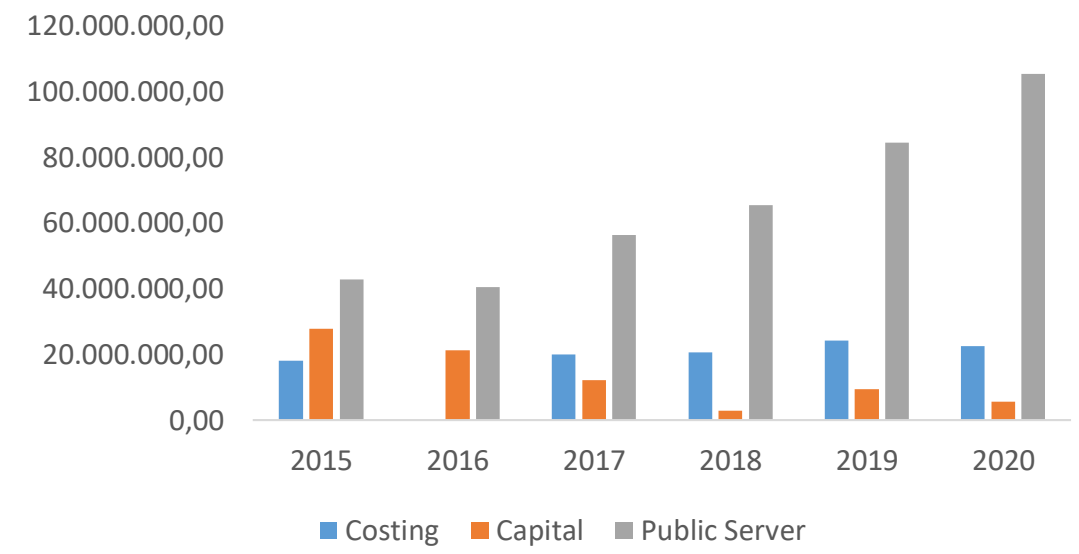

Graphic 3 - Distribution of spent by UNIFESSPA expenditure group 2015 - 2020

Fonte: UNIFESSPA-SEPLAN 2016, UNIFESSPA-SEPLAN 2017a, UNIFESSPA-SEPLAN 2018, UNIFESSPASEPLAN 2019a, UNIFESSPA-SEPLAN 2019b, UNIFESSPA-SEPLAN 2020.

The values of UNIFESSPA's budget destined for pro-rectors, responsible for the coverage of the actions mentioned by the university followed the same trend as the university budget. There was a sharp drop in the values referring to capital expenditure for this 2017 and regressively in the costing, from 2017 to 2018 , from $\mathrm{R} \$ 4.426 .678,00$ to $\mathrm{R} \$ 3.710 .675,00$ at PROEX, the pro-rectory that has the largest resources received over the period.

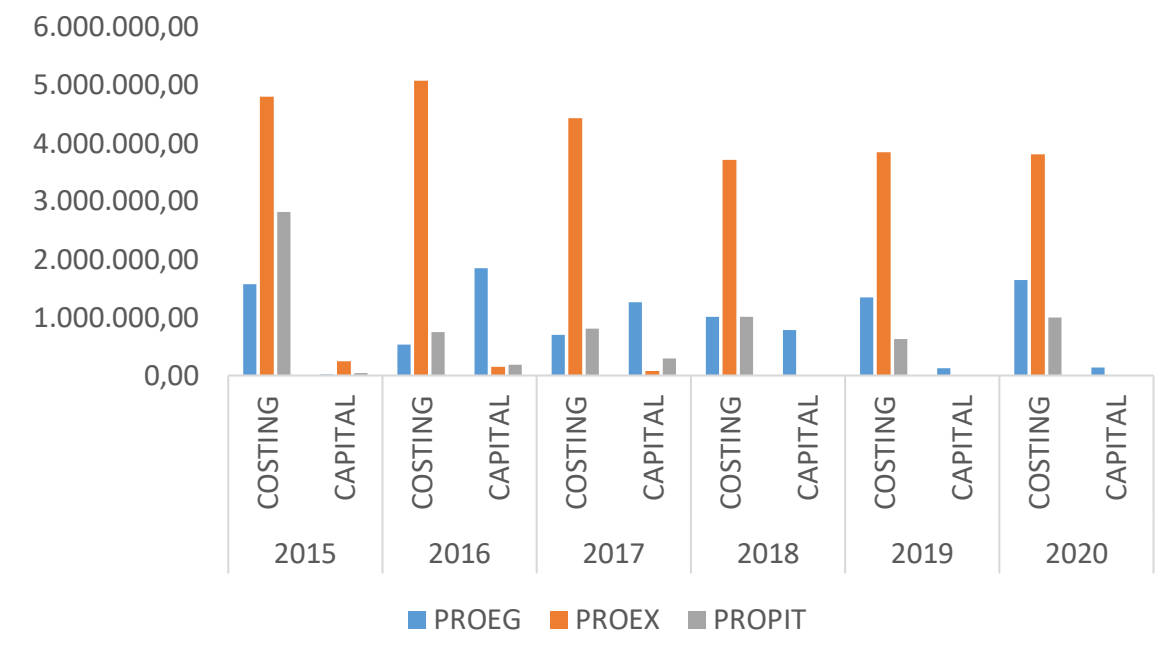

Graphic 4 - Budget of administrative units 2015-2020

Fonte: UNIFESSPA-SEPLAN 2016, UNIFESSPA-SEPLAN 2017a, UNIFESSPA-SEPLAN 2018, UNIFESSPASEPLAN 2019a, UNIFESSPA-SEPLAN 2019b, UNIFESSPA-SEPLAN 2020.

In the years 2013 to 2019 there was a quantitative expansion of UNIFESSPA in a context of reduced investments in education by the federal government. This expansion was achieved by 
expanding the number of undergraduate courses from 16 in 2014 to 43 in 2019, accompanied by an increase in the number of places offered from 1.284 in 2017 to 2.310 in 2018, as well as in the number of students enrolled in undergraduate courses, from 3.973 in 2017 to 4.285 in 2019. These data represented the quantitative expansion of UNIFESSPA in the face of the civil society demands, which should be accompanied by the expansion of resources from the federal government to promote adequate conditions for the actions of this university in southern Pará (UNIFESSPASEPLAN, 2020).

The perception of development for Sen (2000) comes from the freedom of the subjects to have access to social and political rights, among them we highlight the freedom to higher education as a strategy for empowerment through the affirmative actions of the population of the Southeast of Pará, with an emphasis on communities indigenous, quilombolas, riverside, traditional and settlers of the landless movement. The territory has a substantiation on the design of UNIFESSPA strategies due to the recognition by the university of the subjects' territorial identity.

The goal for the construction of a development strategy by the public university runs through the established dialogue of UNIFESSPA with the communities and population of Marabá and the municipalities of the southeastern region of Pará. Democratization to higher education is a sine quo non for the development established by the fronts of the public university: a) training, qualification and diversification of professionals for the local and regional labor market; $b$ ) the foundation of technological and social innovations to meet the demands of the communities, understanding that there is a two-way street, between the popular knowledge of the original peoples and the scientific, and that in this transit of ideas there is the formulation of knowledge with a strong intersection between the cultural and the productive for the generation of social inclusion and income of the population; c) UNIFESSPA can be positioned as a deliberative public space between the population of communities and public policy managers, constituting a space for decisionmaking that can be re-signified by the role of social actors in shaping the public policy agenda of institutional sectors of the federal government with operations in Southeast Pará and municipal governments.

UNIFESSPA took center stage in the Southeast of Pará and its consolidation, as a higher education institution, is a condition for the development of the municipalities in the Southeast of Pará, expanding access to the population to higher education that can mean social changes. However, the abrupt cut in UNIFESSPA's financial resources by the federal government may impair its institutional capacity to capillarize actions to reduce inequalities in the territories of Southeast Pará.

Faced with this context, new institutional arrangements between the university and municipal and state governments are formulated with the purpose of continuing the expansion of UNIFESSPA in Southeast Pará. The cooperation agreement between UNIFESSPA and the city hall of Canaã dos Carajás for the implementation of the Teaching, Research, Extension, Technology and Innovation Pole of Canaã dos Carajás, called Pepeti Canaã dos Carajás, in 2019, can be an unfolding of cooperation agreements to cover the population's demands for higher education and be a strategy for the regional development of Southeast Pará (Unifesspa, 2019c).

The "Forma Pará" Program, of Pará state government with UNIFESSPA, signed in 2020, expanded the offer of undergraduate courses to seven new municipalities Abel Figueiredo, Bom Jesus do Tocantins, Jacundá, Itupiranga, Piçarra, Thailand and Ourilândia do Norte. The courses are Psychology, Veterinary Medicine, Zootechnics, Administration, Accounting, Forest Engineering and Pedagogy. In total, 350 new graduation vacancies will be offered for 2021. (Unifesspa, 2020c). 


\section{FINAL CONSIDERATIONS}

The formulation of the diagnosis of territorial inequalities by the PNDR and the mediation in proposing alternatives for territorial development, combined with the action of REUNI, boosted the formation of a prognosis, with the interiorization of federal higher education, inspired by Amartya Sen's thesis on prioritizing education as a strategy for the individuals developments, achieving freedom to social, political and economic opportunities. This action can generate reverberation on two fronts: economic, in the qualification of the workforce and expansion of the average salary of the worker, by the expansion in new productive activities, expanding the offer of diversified jobs; in the social, in the generation of capacities and empowerment of the population, expanding access to freedom and social opportunities, promoted by education and culture.

The PNDR has refined its guidelines to formulate actions in the territories and through REUNI strengthened the impact of its planning in the micro-regions. UNIFESSPA is the result of the coordination of actions between REUNI and the PDE of the Ministry of Education, in which it made possible the implantation of the federal university and impacted the territory with the offer of places for undergraduate education and places for graduate education, added to the extension actions in the Southeast of Pará.

UNIFESSPA's resource framework in the years 2015 to 2020 corroborates to measure the expansion of public servants, technicians and teachers, in addition to the expansion in the offer of places for undergraduate courses and the number of enrolled students. But, the decrease in investment resources (capital) and the stagnation of resources to accord current expenses (costing) in view of the increase in expenses with maintenance and development of this institution make it impossible to advance its actions in line with the popular demands of the municipalities' territories. with UNIFESSPA campuses and their surroundings, which makes it difficult to accurately measure the effects generated by the university in the period from 2013 to 2020.

Even UNIFESSPA presents serious budgetary restrictions, continues to systematically advance in cooperation agreements with the municipal and state governments of Pará, through cooperation agreements to expand the offer of higher education, with strengthening of the interpretative key of Sen's development, empowerment and training of the population, endorsed by the cultural and productive diversities of the territories of Southeast Pará.

\section{REFERENCES}

Abdal, A. (2020). Trajetórias regionais de desenvolvimento no Brasil contemporâneo: uma agenda de pesquisa. revista brasileira de estudos urbanos e regionais, 22. https://doi.org/10.22296/2317-1529.rbeur.202005

Brandão, C. A. (2007). Território \& desenvolvimento: as múltiplas escalas entre o local e o global. 1. ed. Campinas, SP: Editora da Unicamp.

Brandão, C. A. (2019). Mudanças produtivas e econômicas e reconfiguração territorial no Brasil no início do Século XXI. Revista brasileira de estudos urbanos e regionais. 21(2). https://doi.org/10.22296/2317-1529.2019v21n2p258

Brasil. Ministério da Educação. (2007). Plano de Desenvolvimento da Educação. Brasília: MEC.

Brasil. Ministério De Integração Nacional; Secretaria de Políticas de Desenvolvimento Regional. (2005). Política Nacional de Desenvolvimento Regional. Brasília. Agosto.

Brasil. Ministério De Integração Nacional; Secretaria de Políticas de Desenvolvimento Regional (2010). A PNDR em dois tempos: A experiência apreendida e o olhar pós 2010. Ministério da Integração Nacional (MI) e Secretaria de Políticas de Desenvolvimento Regional. Brasília, DF.

Comissão Econômica para América Latina e Caribe (CEPAL). Educación y conocimiento: eje de la transformación productiva con equidad Cepal - UNESCO (versión resumida). Primeira edición. Lima, marzo, 1996.

Deneulin, S., \& Clausen, J. (2019). Collective Choice and Social Welfare by Amartya Sen: A review essay with reference to development in Peru. Development Policy Review, 37(4), 564-578. https://doi.org/10.1111/dpr.12376 
Dota, E. M., \& Ferreira, F. C. (2020). Evidências da metropolização do espaço no século XXI: elementos para identificação e delimitação do fenômeno. Cadernos Metrópole, 22(49), 893-912. https://doi.org/10.1590/22369996.2020-4910

Feitosa, L. D. C., \& Aranha, P. R. (2020). A “cegueira geográfica” nas políticas públicas territoriais e regionais brasileiras. revista brasileira de estudos urbanos e regionais, 22. https://doi.org/10.22296/2317-1529.rbeur.202018

Gao, J., Yu, Z., Wang, L., \& Vejre, H. (2019). Suitability of regional development based on ecosystem service benefits and losses: A case study of the Yangtze River Delta urban agglomeration, China. Ecological Indicators, $107,105579$. https://doi.org/10.1016/j.ecolind.2019.105579

Gentil, P. P. D. C., Guimarães, L. D. O., Pereira, D. D. C., Diniz, A. M., \& Ckagnazarof, I. B. (2019). Governança territorial e inovação social nos processos de desenvolvimento regional em territórios de mineração: um modelo teórico em construção. Cadernos EBAPE. BR, 17(3), 509-522. https://doi.org/10.1590/1679-395173778

Grisotti, M., Felipe, M. R., \& Ramos, A. M. (2020). Desenvolvimento regional e aceitabilidade social de grandes projetos de infraestrutura: o caso da Câmara Técnica de saúde do PDRS do Xingu. Civitas-Revista de Ciências Sociais, 20(1), 32-42. https://doi.org/10.15448/1984-7289.2020.1.34641

Jung, W. (2020). Two models of community-centered development in Myanmar. World Development, $136,105081$. https://doi.org/10.1016/j.worlddev.2020.105081

Lotta, G.; Favareto, A. (2018). Os arranjos institucionais de coordenação dos investimentos em infraestrutura no brasil: uma análise sobre seis grandes projetos do programa de aceleração do crescimento. In: GOMIDE, A. \& PEREIRA, A.K. (org.). Governança da política de infraestrutura - condicionantes institucionais ao investimento. Brasília: IPEA.

Macedo, F. C., \& Porto, L. (2018). Existe uma Política Nacional de Desenvolvimento Regional no Brasil?. Revista Brasileira de Gestão e Desenvolvimento Regional, 14(2).

Macedo, F., Pires, M., \& Sampaio, D. (2017). 25 anos de Fundos Constitucionais de Financiamento no Brasil: avanços e desafios à luz da Política Nacional de Desenvolvimento Regional. EURE (Santiago), 43(129), 257-277. https://doi.org/10.4067/s0250-71612017000200012

Marques, A. C. H., Cepêda, V. A. (2012). Um perfil sobre a expansão do ensino superior recente no Brasil: Aspectos democrático e inclusivos. Perspectiva, São Paulo, 42, 161-192.

Mok, K., \& Jeong, W. (2016). Revising Amartya Sen's capability approach to education for ethical development. Asia Pacific Education Review, 17(3), 501-510. https://doi.org/10.1007/s12564-016-9449-2

Oecd. (2007). La Educación Superior y las Regiones Globalmente Competitivas, Localmente Comprometidas, Paris: OCDE. OECD Publishing. https://doi.org/10.1787/9789264064690-es

Paula, C. H. D., \& Almeida, F. M. D. (2020). Reuni program and performance of brazilian Ifes. Ensaio: Avaliação e Políticas Públicas em Educação, 28(109), 1054-1075. https://doi.org/10.1590/s0104-40362020002801869

Santos, T. D. S., \& Pereira, R. D. S. (2020). O turismo como impulsionador do desenvolvimento regional: análise no Campo das Vertentes (mg), Brasil. EURE (Santiago), 46(137), 113-133. https://doi.org/10.4067/s0250$\underline{71612020000100113}$

Sen, A. K. (2000). Desenvolvimento como Liberdade. Tradução Laura Teixeira Motta; revisão técnica Ricardo Doniselli Mendes. - São Paulo: Companhia das Letras.

Stoffel, J., Rambo, A. G., \& Freitas, T. D. (2019). Escalas do desenvolvimento: análises a partir da PNDR e da política territorial no Brasil. Revista Brasileira de Gestão e Desenvolvimento Regional, 15(7).

Unifesspa. Seplan, Secretária de Planejamento e Desenvolvimento Institucional. (2016). Relatório de Gestão 2015. Universidade Federal do Sul e Sudeste do Pará, Marabá.

Unifesspa. Seplan, Secretária de Planejamento e Desenvolvimento Institucional. (2017a). Relatório de Gestão 2016. Universidade Federal do Sul e Sudeste do Pará, Marabá.

Unifesspa. Seplan, Secretária de Planejamento e Desenvolvimento Institucional. (2017b). Unifesspa em números 2018 (ano base 2017).

Unifesspa. Seplan, Secretária de Planejamento e Desenvolvimento Institucional. (2018). Relatório de Gestão 2017. Universidade Federal do Sul e Sudeste do Pará, Marabá.

Unifesspa. Seplan, Secretária de Planejamento e Desenvolvimento Institucional (2019a). Relatório de Gestão 2018. Universidade Federal do Sul e Sudeste do Pará, Marabá.

Unifesspa. Seplan, Secretária de Planejamento e Desenvolvimento Institucional. (2019b). Plano de Gestão Orçamentária 2019. Universidade Federal do Sul e Sudeste do Pará, Marabá. 
Unifesspa. (2019c). Unifesspa assina acordo para implantação de polo educacional em Canaã e oferta cursos a partir de julho. https://www.unifesspa.edu.br/noticias/3540-unifesspa-assina-acordo-para-implantacao-de-polo-educacional-emcanaa-e-oferta-cursos-a-partir-de-julho accessed Octuber 02, 2020.

Unifesspa. Seplan, Secretária de Planejamento e Desenvolvimento Institucional. (2020a). Plano de Gestão Orçamentária 2020. Universidade Federal do Sul e Sudeste do Pará, Marabá.

Unifesspa. Seplan, Secretária de Planejamento e Desenvolvimento Institucional. (2020b). Plano de Desenvolvimento Institucional (PDI) 2014-2020. Universidade Federal do Sul e Sudeste do Pará, Marabá.

Unifesspa. (2020c). Forma Pará: População de sete municípios comemora oferta de cursos superiores pela Unifesspa https://www.unifesspa.edu.br/noticias/4762-forma-para-populacao-de-sete-municipios-comemora-oferta-de-cursossuperiores-pela-unifesspa acessed Octuber, 02, 2020

Vicente, P. N., Lucas, M., Carlos, V., \& Bem-Haja, P. (2020). Higher education in a material world: Constraints to digital innovation in Portuguese universities and polytechnic institutes. Education and Information Technologies, 1-19. https://doi.org/10.1007/s10639-020-10258-5

Walker, M. (2020). Failures and possibilities of epistemic justice, with some implications for higher education. Critical Studies in Education, 61(3), 263-278. https://doi.org/10.1080/17508487.2018.1474774

Xiang, L., Stillwell, J., Burns, L., \& Heppenstall, A. (2020). Measuring and Assessing Regional Education Inequalities in China under Changing Policy Regimes. Applied Spatial Analysis and Policy, 13(1), 91-112. https://doi.org/10.1007/s12061-019-09293-8

Zhang, G., Wu, J., \& Zhu, Q. (2020). Performance evaluation and enrollment quota allocation for Higher Education Institutions in China. Evaluation and Program Planning, 101821. https://doi.org/10.1016/j.evalprogplan.2020.101821 
DECLARATION OF CONTRIBUTIONS TO THE ARTICLE - CRediT

\begin{tabular}{|c|c|c|}
\hline ROLE & RGumiero & ATigre \\
\hline Conceptualization - Ideas; formulation or evolution of overarching research goals and aims. & $\mathrm{X}$ & $\mathrm{X}$ \\
\hline $\begin{array}{l}\text { Data curation - Management activities to annotate (produce metadata), scrub data and maintain } \\
\text { research data (including software code, where it is necessary for interpreting the data itself) for } \\
\text { initial use and later re-use. }\end{array}$ & & $\mathrm{X}$ \\
\hline $\begin{array}{l}\text { Formal analysis - Application of statistical, mathematical, computational, or other formal } \\
\text { techniques to analyze or synthesize study data. }\end{array}$ & & $\mathrm{X}$ \\
\hline $\begin{array}{l}\text { Funding acquisition - Acquisition of the financial support for the project leading to this } \\
\text { publication. }\end{array}$ & $\mathrm{X}$ & \\
\hline $\begin{array}{l}\text { Investigation - Conducting a research and investigation process, specifically performing the } \\
\text { experiments, or data/evidence collection. }\end{array}$ & $\mathrm{X}$ & $\mathrm{X}$ \\
\hline Methodology - Development or design of methodology; creation of models. & $\mathrm{X}$ & \\
\hline $\begin{array}{l}\text { Project administration - Management and coordination responsibility for the research activity } \\
\text { planning and execution. }\end{array}$ & $\mathrm{X}$ & \\
\hline $\begin{array}{l}\text { Resources - Provision of study materials, reagents, materials, patients, laboratory samples, } \\
\text { animals, instrumentation, computing resources, or other analysis tools. }\end{array}$ & $\mathrm{X}$ & \\
\hline $\begin{array}{l}\text { Software - Programming, software development; designing computer programs; } \\
\text { implementation of the computer code and supporting algorithms; testing of existing code } \\
\text { components. }\end{array}$ & - & - \\
\hline $\begin{array}{l}\text { Supervision - Oversight and leadership responsibility for the research activity planning and } \\
\text { execution, including mentorship external to the core team. }\end{array}$ & $\mathrm{X}$ & \\
\hline $\begin{array}{l}\text { Validation - Verification, whether as a part of the activity or separate, of the overall } \\
\text { replication/reproducibility of results/experiments and other research outputs. }\end{array}$ & $\mathrm{X}$ & $\mathrm{X}$ \\
\hline $\begin{array}{l}\text { Visualization - Preparation, creation and/or presentation of the published work, specifically } \\
\text { visualization/data presentation. }\end{array}$ & & $\mathrm{X}$ \\
\hline $\begin{array}{l}\text { Writing - original draft - Preparation, creation and/or presentation of the published work, } \\
\text { specifically writing the initial draft (including substantive translation). }\end{array}$ & $\mathrm{X}$ & \\
\hline $\begin{array}{l}\text { Writing - review \& editing - Preparation, creation and/or presentation of the published work by } \\
\text { those from the original research group, specifically critical review, commentary or revision - } \\
\text { including pre- or post-publication stages. }\end{array}$ & $X$ & $X$ \\
\hline
\end{tabular}

